\section{'KnuckleHull-VNR', a Crowder-type Southernpea Resistant to Blackeye Cowpea Mosaic Virus and Root-knot Nematode}

\author{
Richard L. Fery ${ }^{1}$ and Judy A. Thies ${ }^{2}$ \\ U.S. Department of Agriculture, Agricultural Research Service, U.S. Vegetable \\ Laboratory, 2700 Savannah Highway, Charleston, SC 29414-5334
}

\begin{abstract}
A. Graves Gillaspie ${ }^{2}$
Plant Genetic Resources Conservation Unit, Agricultural Research Service, U.S. Department of Agriculture, 1109 Experiment Street, Griffin, GA 30223-1797
\end{abstract}

Additional index words. Vigna unguiculata, cowpea, soil-borne pathogen, Meloidogyne, disease resistance, vegetable breeding

'KnuckleHull-VNR' is a new southernpea [Vigna unguiculata (L.) Walp.] released 18 Oct. 2002 by the U.S. Dept. of Agriculture, Agricultural Research Service(USDA-ARS). 'KnuckleHull-VNR' was developed as a replacement for 'Knuckle Purple Hull', a crowder-type cultivar widely grown by home gardeners throughout the southeastern United States for many years despite susceptibility to blackeye cowpea mosaic virus (BlCMV) and root-knot nematodes (Meloidogyne spp.). The major attributes of the new cultivar are its excellent resistances to BlCMV and root- knot nematodes.

\section{Origin}

Efforts to develop 'KnuckleHull-VNR' were initiated in 1997 with the field evaluation at Charleston, S.C., of a collection of 61 knuckle purple hull-type breeding lines received from Auburn Univ. at the closeout of its southernpea breeding program. Exact pedigrees and degree of inbreeding of the original lines are unknown, but each line was believed to be the result of a cross between US-427 and an Auburn Univ. B1CMV-resistant, knuckle purple hull-type breeding line. US-427 is a root-knot nematode resistant breeding line developed at the U.S. Vegetable Laboratory and released in 1987; it is the product of a recurrent backcross breeding effort (five backcrosses) to incorporate the dominant $R k$ gene for root-knot nematode resistance into 'Knuckle Purple Hull' (Fery and Dukes, 1988). Patel (1985) noted that 'Worthmore' was used in the Auburn Univ. southernpea breeding program to improve 'Knuckle Purple Hull' for BlCMV resistance; Walker and Chambliss (1981) reported that a

Received for publication 3 Dec. 2002. Accepted for publication 26 Mar. 2003. We thank Oyette Chambliss and Gene Hunter for providing seed of knuckle purple hull-type southernpea breeding lines at the closeout of the breeding program at Auburn Univ. The technical assistance of F.P. Maguire, E.L. Corley, Jr., and S.W. Miller is gratefully acknowledged.

${ }^{1}$ Research Geneticist.

${ }^{2}$ Research Plant Pathologist. single recessive gene $(b l c)$ controls BICMV resistance in 'Worthmore'. The 61 lines in the 1997 field planting were subjected to a selection effort between and within lines to develop homozygous, knuckle purple hull-type populations. Progenies of single plants selected from the 1997 field planting were grown in a Winter 1997-98 greenhouse planting and an additional cycle of single-plant selection was completed. 'KnuckleHull-VNR' originated as the bulk of the progeny of one of the Winter 1997-98 single-plant selections grown in a Spring 1998 greenhouse planting.

\section{Description}

Plant and pod characteristics of 'KnuckleHull-VNR' are quite similar to those of 'Knuckle Purple Hull' (Fig. 1). 'KnuckleHull-VNR' has a high bushy growth habit and produces dry pods at Charleston, S.C., in 68 to $74 \mathrm{~d}$. Flower color is purple (completely pigmented). There is extensive purple pigmentation on the stems, branches, and peduncles, but only intermediate pigmentation on petioles. 'KnuckleHull-VNR' has smooth, nonglossy, green- colored leaves. Pod set is concentrated, southernpea. and pods are borne above foliage level in a scattered fashion. Dry pods are attached to the peduncles in a pendant fashion. Each peduncle typically produces two pods.

A typical 'KnuckleHull-VNR' pod is slightly curved, $20 \mathrm{~cm}$ long, and contains 14 peas (Fig. 2). Pod color is light green (with purple pigmentation at both ends) when immature, purple (glossy) at optimum greenshell maturity, and dark purple (nonglossy) when dry. Fresh peas have a semi-crowder to crowder shape and a light green color. Dry 'KnuckleHull-VNR' peas have a brown-colored, smooth seedcoat, and are smaller than 'Knuckle Purple Hull' (weight per 100 dry peas: 'KnuckleHull-VNR', 15.2 g, and 'Knuckle Purple Hull', 19.7 g) (Table 1).

Results of 3 years (1999-2001) of replicated field testing at Charleston, S.C., indicate yield potential of 'KnuckleHull-VNR' is similar to that of 'Knuckle Purple Hull' ('KnuckleHullVNR' yield of dry peas over the entire 3-year period of replicated testing was $107 \%$ of the yield of 'Knuckle Purple Hull') (Table 1). 'KnuckleHull-VNR' was tested as US-1035 throughout the southern United States in the 2000 and 2001 Regional Southernpea Cooperative Trials.

The results of an inoculated greenhouse test and 3 years (1999-2001) of inoculated (susceptible spreader row technique) field tests conducted at Griffin, Ga., using enzyme-linked immunosorbent assay methodology indicate that 'KnuckleHull-VNR' is highly resistant to BlCMV. This demonstrated resistance to BlCMV indicates that 'KnuckleHull-VNR' is also resistant to cowpea stunt, an extremely devastating viral disease caused by a synergistic effect of BlCMV and cucumber mosaic virus (Pio-Ribeiro et al., 1978).

'KnuckleHull-VNR' is homozygous for the $R k$ gene that conditions resistance to southern root-knot nematode $[M$. incognita (Kofoid and White) Chitwood], Javanese root-knot nematode [M. javanica (Treub.) Chitwood], and northern root-knot nematode [M. hapla Chitwood] (Fery and Dukes, 1980). A South Carolina isolate of $M$. incognita race 3 was used to bioassay for presence of the $R k$ gene during the development of 'KnuckleHull-VNR',

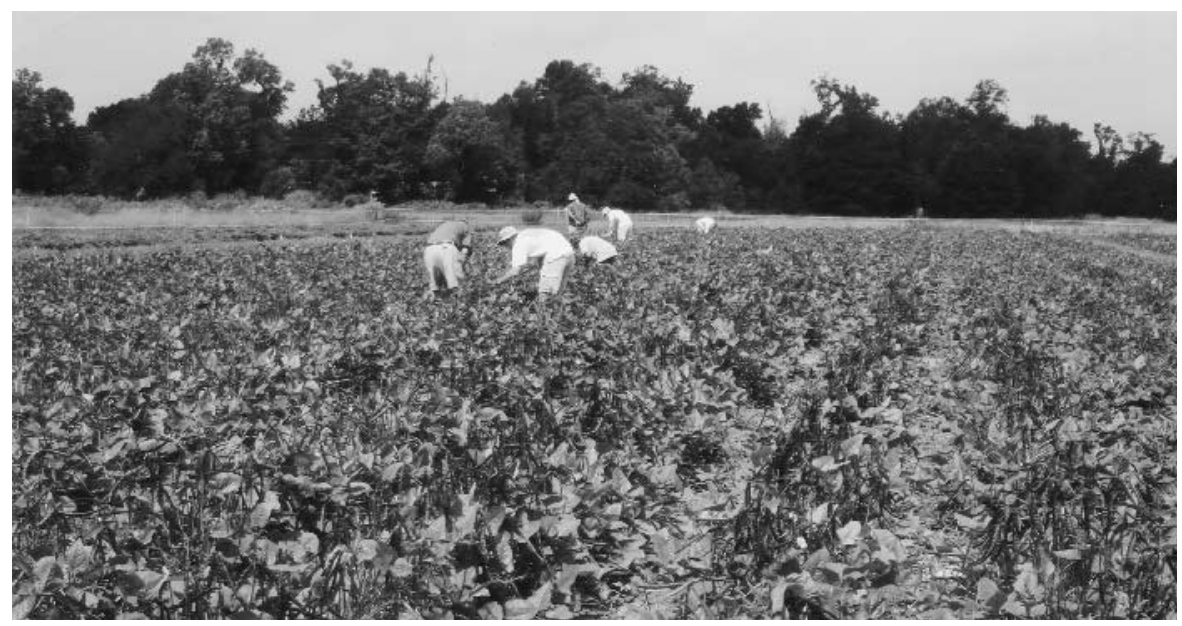

Fig. 1. Space-planted field (single plants spaced $90 \mathrm{~cm}$ apart on beds $102 \mathrm{~cm}$ apart) of 'KnuckleHull-VNR' 
Table 1 . Number of days to harvest, weight per 100 dry peas, and dry pea yield for 'KnuckleHull-VNR' and 'Knuckle Purple Hull' southernpeas grown in spring trials, Charleston, S.C., 1999-2001. ${ }^{\mathrm{z}}$

\begin{tabular}{|c|c|c|c|}
\hline Cultivar & $\begin{array}{c}\text { Days to } \\
\text { harvest (no.) }\end{array}$ & $\begin{array}{c}\mathrm{Wt} / 100 \\
\text { dry peas }(\mathrm{g})\end{array}$ & $\begin{array}{c}\text { Dry pea yield } \\
\left(\mathrm{kg} \cdot \mathrm{ha}^{-1}\right)\end{array}$ \\
\hline \multicolumn{4}{|c|}{ Trial 1-1999 } \\
\hline KnuckleHull-VNR & $68.6 b^{y}$ & $14.6 \mathrm{~b}$ & $960 \mathrm{a}$ \\
\hline Knuckle Purple Hull & $70.4 \mathrm{a}$ & $17.5 \mathrm{a}$ & $583 \mathrm{~b}$ \\
\hline \multicolumn{4}{|c|}{ Trial II-2000 } \\
\hline KnuckleHull-VNR & $74.5 \mathrm{~b}$ & $16.0 \mathrm{~b}$ & $993 \mathrm{a}$ \\
\hline Knuckle Purple Hull & $86.5 \mathrm{a}$ & $22.4 \mathrm{a}$ & 938 a \\
\hline \multicolumn{4}{|c|}{ Trial III-2001 } \\
\hline KnuckleHull-VNR & $74.2 \mathrm{a}$ & $15.1 \mathrm{~b}$ & $796 \mathrm{~b}$ \\
\hline Knuckle Purple Hull & $73.9 \mathrm{a}$ & $19.2 \mathrm{a}$ & $1,048 \mathrm{a}$ \\
\hline \multicolumn{4}{|c|}{ Combined analysis of all trials } \\
\hline KnuckleHull-VNR & $72.4 \mathrm{~b}^{* * * *}$ & $15.2 \mathrm{~b}^{* * * *}$ & $916 \mathrm{a}^{* * *}$ \\
\hline Knuckle Purple Hull & $76.9 \mathrm{a}$ & $19.7 \mathrm{a}$ & $856 \mathrm{a}$ \\
\hline
\end{tabular}

${ }^{\mathrm{z}}$ Spring 1999, 2000, and 2001 trials planted on 2 June, 1 June, and 5 June, respectively. Experimental design of each trial was a randomized complete block with 10 replications. Results of combined analyses of all trials indicated a significant cultivar $\times$ trial interaction for days to harvest, weight per 100 dry peas, and dry pea yield. Consequently, results are presented for both single trial and combined analyses to aid interpretation.

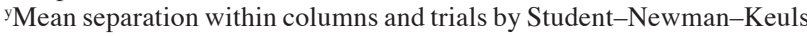
multiple range test, $P<0.05$.

*** Significant interaction between cultivar and trial at $P<0.001$.
Table 2. Average root gall index, average egg mass index, and average number of eggs per gram fresh root tissue for 'KnuckleHull-VNR', 'Knuckle Purple Hull', US-427, 'Mississippi Silver', and 'Pinkeye Purple Hull-BVR' plants grown in soil infested with the southern root-knot nematode, Meloidogyne incognita race 3 (Greenhouse Expt.). ${ }^{\mathrm{z}}$

\begin{tabular}{lccc}
\hline Cultivar & $\begin{array}{c}\text { Root gall } \\
\text { index }^{\mathrm{y}}\end{array}$ & $\begin{array}{c}\text { Egg mass } \\
\text { index }^{\mathrm{x}}\end{array}$ & $\begin{array}{c}\text { No. of eggs/g } \\
\text { fresh root tissue }\end{array}$ \\
\hline KnuckleHull-VNR & $1.50 \mathrm{~b}^{\mathrm{w}}$ & $1.37 \mathrm{~b}$ & $14,306 \mathrm{~b}$ \\
Knuckle Purple Hull & $4.97 \mathrm{a}$ & $4.97 \mathrm{a}$ & $109,336 \mathrm{a}$ \\
US-427v $^{v}$ & $1.50 \mathrm{~b}$ & $1.42 \mathrm{~b}$ & $7,800 \mathrm{~b}$ \\
Mississippi Silver $^{v}$ & $1.50 \mathrm{~b}$ & $1.22 \mathrm{~b}$ & $16,038 \mathrm{~b}$ \\
Pinkeye Purple Hull-BVR $^{\mathrm{u}}$ & $4.93 \mathrm{a}$ & $4.98 \mathrm{a}$ & $118,644 \mathrm{a}$ \\
\hline
\end{tabular}

${ }^{2}$ Randomized complete-block experiment with six replications (five plants per plot; seeds sowed in a steam-pasteurized mixture of soil, sand, and peat on 25 Feb. 1999; each seed inoculated with $\approx 2700$ M. incognita race 3 eggs at sowing; roots of all plants evaluated for galling and egg masses on 27 May 1999). The $\mathrm{NaOCl}$ procedure described by Hussey and Barker (1973) was used to extract $M$. incognita eggs from a fibrous root sample taken from each plot.

${ }^{y}$ Rated on a scale of 1 to $5: 1=$ no galls; 2 = light galling, $1 \%$ to $25 \%$ of root system galled; $3=$ moderate galling, $26 \%$ to $50 \%$ of root system galled; $4=$ heavy galling, $51 \%$ to $80 \%$ of root system galled; and $5=$ severe galling, $81 \%$ to $100 \%$ of root system galled.

${ }^{x}$ Rated on a scale of 1 to 5: 1 = no egg masses evident, 2 = scattered egg masses covering $1 \%$ to $25 \%$ of root system, $3=$ moderate number of egg masses covering $26 \%$ to $50 \%$ of root system, $4=$ numerous egg masses covering $51 \%$ to $80 \%$ of root system, and $5=$ extremely large number of egg masses covering $81 \%$ to $100 \%$ of root system.

wMean separation within columns by Student-Newman-Keuls multiple range test, $P<0.05$.

'Resistant control.

"Susceptible control. and results of all greenhouse tests indicated that resistance exhibited by 'KnuckleHull-VNR' is equal to the resistance exhibited by the widely grown crowder-type cultivar Mississippi Silver. Numbers of galls and egg masses on the roots were always minimal. Results of a 1999 replicated test conducted in a soil-filled greenhouse bench infested with $M$. incognita showed that fresh 'KnuckleHull-VNR' roots yielded $87 \%$ fewer $M$. incognita eggs/gram than did fresh 'Knuckle Purple Hull' roots (Table 2).

'KnuckleHull-VNR' is recommended for

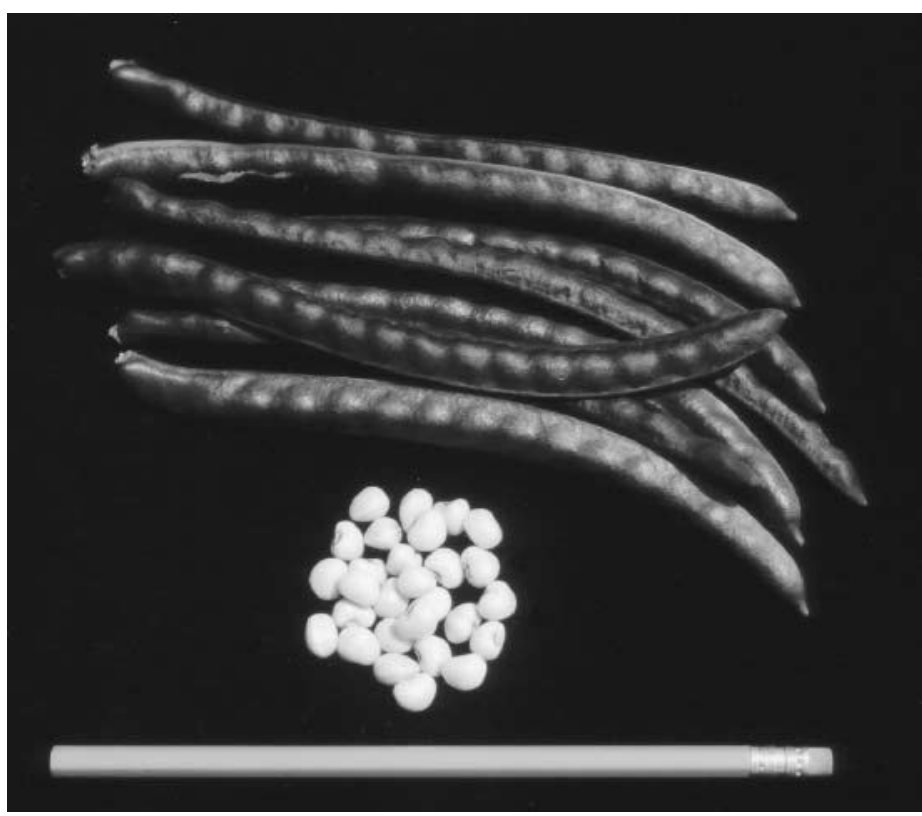

Fig. 2. Fresh pods and peas of 'KnuckleHull-VNR' southernpea. successfully grown. use by home gardeners who are concerned about yield losses to their 'Knuckle Purple Hull' plantings caused by BlCMV, cowpea stunt, and root-knot nematodes. BICMV and cowpea stunt can cause devastating yield losses to southernpeas in home gardens, and plant resistance is the only feasible method of control. Home gardeners often do not have easy access to needed nematicides or garden sites not infested with root-knot nematodes. 'KnuckleHull-VNR' should perform well in all areas where 'Knuckle Purple Hull' has been$$
\text { (1) }
$$

(1)

\section{Availability}

Breeder's seed of 'KnuckleHull-VNR' has been released to seed producers. Small samples of 'KnuckleHull-VNR' breeder's seed are available from R.L.F. for distribution to interested research personnel. Genetic material of this release will be deposited in the National Plant Germplasm System where it will be available for research purposes, including the development and commercialization of new cultivars. It is requested that appropriate recognition of source be given when this germplasm contributes to research or development of a new breeding line or cultivar.

\section{Literature Cited}

Fery, R.L. and P.D. Dukes. 1980. Inheritance of root-knot nematode resistance in cowpea [Vigna unguiculata (L.) Walp.]. J. Amer. Soc. Hort. Sci. 105:671-674.

Fery, R.L. and P.D. Dukes. 1988. US-311 and US427 southernpea breeding lines. HortScience 23:643-644.

Hussey, R.S. and K.R. Barker. 1973. A comparison of methods of collecting inocula of Meloidogyne spp., including a new technique. Plant Dis. Rptr. 57:1025-1028.

Patel, P.N. 1985. Fungal, bacterial and viral diseases of cowpea in the USA, p. 205-213. In: S.R. Singh and K.O. Rachie (eds.). Cowpea research, production and utilization. Wiley, Chichester, U.K.

Pio-Ribeiro, G., S.D. Wyatt, and C.W. Kuhn. 1978. Cowpea stunt: A disease caused by a synergistic interaction of two viruses. Phytopathology 68: 1260-1265.

Walker, C.A., Jr., and O.L. Chambliss. 1981. Inheritance of resistance to blackeye cowpea mosaic virus in Vigna unguiculata (L.) Walp. J. Amer. Soc. Hort. Sci. 106:410-412. 